\title{
Personal Care Product
}

National Cancer Institute

\section{Source}

National Cancer Institute. Personal Care Product. NCI Thesaurus. Code C126889.

A consumer product used for personal hygiene or for beautification. 